\title{
Land use in the Manawatu
}

\author{
E. HURLEY and B. WALLACE \\ MAF Policy, P.O. Box 1654, Palmerston North \\ hurleye@maf.govt.nz
}

\begin{abstract}
Land use is described by a combination of statistical data, MAF monitoring (using a representative model to characterise the farm) and historical case studies. The ways in which the region's farmers have adapted to the changing environment, both economic and biophysical, is described. Science and education are essential infrastructural elements of this region.
\end{abstract}

Keywords: case studies, farm monitoring, statistics

\section{Introduction}

Land use in any region is difficult to describe and even more so when the landscapes of the region are diverse, hard to define and blurry at the margins. Manawatu-Wanganui is a region that varies from highly productive lowland soils with a wide range of potential uses, through to hill and some hard hill country with limited agricultural possibilities. While it is useful to know about current land use in this paper we will attempt to paint a picture of the changes that have occurred over recent years.

A characteristic of farming in this region is that its resources are versatile and opportunities exist to respond to market signals. Land use has changed in the 26 years since the last Grasslands conference here. Those trends are not readily apparent in the statistics so some case studies and other data will be used to help tell the stories.

So the paper will consist of:

- Some statistical information, from recent (2002) and previous censuses.

- Farm production and productivity information based on regional farm monitoring as carried out by MAF.

- Farm histories of three contrasting farm types to demonstrate the kinds of changes since 1977.

\section{Statistics and other data}

Over recent years the bases for collection of data have changed and at times it is difficult to be confident that one is telling a realistic story. For the decade prior to 1999 the collection of agricultural statistics was minimised and it has taken some effort on the part of MAF working with Statistics New Zealand to regain the momentum needed to provide reliable (consistent and appropriate) data of our major industries. From 2002 onwards there will be a full census every five years. In addition sample surveys $(8-10 \%$ of population) will be carried out each year to enable updating of the data.

The Horizons Regional Council (ManawatuWanganui) region was chosen since most of the agricultural data (Statistics New Zealand and MAF Monitoring) are collected on a regional basis.

MAF Farm Monitoring information enables us to generate "typical" or representative farms on a regional basis to help understand changing farm policies, production and economics. Together with some farm case histories we can describe the changes that have been taking place.

Table 1 shows crude land use data for the region and New Zealand. It is not clear whether reduction in "agricultural" land has resulted from land retirement or from a redefinition of eligible land (perhaps a combination of both). Land under horticulture has reduced significantly. Of note is the significant increase in planted production forests. About $50 \%$ of this is privately owned. The marked increase in "other" land may reflect the rise of lifestyle blocks.

Table 2 shows data on farm and livestock numbers and crop areas as best can be derived from recent surveys and censuses, including 2002 data just released at the time of writing.

Table 1 Land use as at 30 June 1994 and 2002.

\begin{tabular}{llccccc}
\hline & & $\begin{array}{c}\text { Grazing, arable, } \\
\text { fodder and fallow } \\
\text { land ('000 ha) }\end{array}$ & $\begin{array}{c}\text { Horticulture land } \\
\text { ('000 ha) }\end{array}$ & $\begin{array}{c}\text { Planted production } \\
\text { forest ('000 ha) }\end{array}$ & $\begin{array}{c}\text { Other land } \\
\text { ('000 ha) }\end{array}$ & $\begin{array}{c}\text { Total land } \\
\text { ('000 ha) }\end{array}$ \\
\hline Manawatu/ & 1994 & 1420 & 7.3 & 83.6 & 110.2 & 1621 \\
Wanganui & 2002 & 1216 & 4.9 & 140.2 & 182.7 & 1543 \\
& $\%$ change & -14 & -33 & 68 & 66 & -5 \\
New & 1994 & 13536 & 103.8 & 1488 & 1479 & 16607 \\
Zealand (ha) & 2002 & 12004 & 109.4 & 1880 & 1678 & 15671 \\
& $\%$ change & -11 & 5 & 26 & 13 & -6 \\
\hline
\end{tabular}


Table 2 Farm type (1994-2002).

\begin{tabular}{|c|c|c|c|c|c|c|}
\hline \multirow[t]{2}{*}{ Farm type } & \multicolumn{2}{|c|}{$\longrightarrow 1994 \longrightarrow$} & \multicolumn{2}{|c|}{$-1999^{*} \longrightarrow$} & \multicolumn{2}{|c|}{$-2002-$} \\
\hline & $\begin{array}{l}\text { No. of } \\
\text { farms }\end{array}$ & $\begin{array}{c}\text { Stock nos. } \\
\text { ('000) }\end{array}$ & $\begin{array}{l}\text { No. of } \\
\text { farms }\end{array}$ & $\begin{array}{l}\text { Stock nos. } \\
\text { ('000) }\end{array}$ & $\begin{array}{l}\text { No. of } \\
\text { farms }\end{array}$ & $\begin{array}{c}\text { Stock nos. } \\
\text { ('000) }\end{array}$ \\
\hline Dairy & 1265 & 308 & 1100 & 251\# & n.a. & 421 \\
\hline Sheep \& & & 7458 & & 6956 & & 6582 \\
\hline Beef cattle & 3150 & 825 & 3690 & 752 & n.a. & 725 \\
\hline Deer & 178 & 129 & 56 & 150 & n.a. & 145 \\
\hline
\end{tabular}

\# Milking cows.

About 1000 of the 3690 sheep and beef cattle farms might be called "intensive" although the definition is vague and the boundary between them and their hill country neighbours fuzzy. Dairy farm numbers have held and stock numbers increased. Note that total sheep numbers and cattle numbers have decreased by $12 \%$ while total dairy numbers have increased by $37 \%$ and deer numbers by $12 \%$. The composition of the sheep flock is about the same and breeding ewe numbers in this area have dropped by only $13 \%$ compared to the national drop of $22 \%$.

Data on the number of properties are not currently available but in 1990 there were around 5070 farms. The number may have slightly reduced by now due to amalgamations but offset by lifestyle block developments.

There are some early plantings of both grapes and

Table 3 Horticulture and arable crops.

\begin{tabular}{lccc}
\hline Farm type & 1994 & $1999^{\star}$ & 2002 \\
\hline Horticulture (No. of properties) & 410 & 220 & n.a. \\
Wheat (ha) & 3600 & n.a. & 1280 \\
Barley (ha) & 7800 & n.a. & 5443 \\
\hline${ }^{*}$ Based on survey data. & & & \\
\hline
\end{tabular}

olives in the region, with 25 ha of wine grapes and 57 ha of olives recorded. The area planted in apples dropped from 100 ha in 1994 to 44 ha in 2002. The areas of some vegetables have risen steadily. Onion plantings have risen from 100 to 282 ha. Squash now covers 692 ha, up from 300 ha over the survey period. And the region's indoor tomato area has risen by $100 \%$ - up from $22 \mathrm{~m}^{2}$ to $44580 \mathrm{~m}^{2}$. As shown in Table 3 the area of wheat and barley grown in the region has declined significantly. Wheat is down 64\% from 1994 while barley declined by $30 \%$.

\section{Dairy farming in the region}

Table 4 compares 1994 with 2002. In 1994 milksolids prices were trending downwards, differential shoulder milk prices were being introduced and farmers were required to pay a premium on new shares (for increased supply). 1994 was a one-in-ten year drought while 2002 was an extremely good year in both financial and weather terms. Over the period cow numbers have increased by $37 \%$, farms have amalgamated and dairy conversions have occurred. The development of the sand country into large-scale dairy units has occurred alongside the advent of irrigation in the region. Control and management of the region's water resources is now a major dairying issue.

\section{Sheep and cattle farming in the region}

There are around 3600 sheep and cattle farms in the region of which about 1000 would rate as "intensive". A typical intensive farmer runs a breeding flock and much of the income comes from finishing the farmer's own and purchased lambs and cattle, which typically includes beef of dairy origin. Also in the mix may be grazing dairy cows and/or young stock. If the landscape is suitable for cash cropping this might also be in the form of maize for silage for dairy farms. The livestock component of this kind of operation is highly dependent on the neighbouring farm systems, and when the balance of farms changes at the margin so too must these systems adapt to the extent they are able. At the margin the pattern is volatile with many dairy conversions over the last ten years and an increasing need for feed sources as dairy milking platforms
Table 4 MAF Farm Monitoring data for typical Manawatu-Wanganui owneroperated dairy farms.

\begin{tabular}{lll}
\hline & 1994 & $2002^{*}$ \\
\hline $\begin{array}{l}\text { No. of farms in } \\
\text { Manawatu/Wanganui }\end{array}$ & 1289 & 1300 (approx.) \\
Effective area (ha) & 75 & 85 \\
Peak cows milked & 165 & 207 \\
Production (kg MS) & 47600 & 65000 \\
Milksolids price (c/kg MS) & 346 & 527 \\
Cash farm surplus (\$) & $87150(99430$ in 2002) & 172830 \\
Cash farm surplus/ha (\$) & 1162 (1326 in 2002) & 2033 \\
\hline * Based on all Fonterra suppliers in the lower North Island.
\end{tabular}


Table 5 Manawatu/Rangitikei sheep and beef cattle Farm Monitoring Models.

\begin{tabular}{lcccc}
\hline & \multicolumn{2}{c}{$\begin{array}{c}\text { Finishing } \\
\text { (intensive) farms }\end{array}$} & \multicolumn{2}{c}{ Hill country farms } \\
& 1994 & 2002 & 1994 & $2002^{*}$ \\
Effective area (ha) & 155 & 393 & 373 & 550 \\
Ewes (no) & 1300 & 1515 & 2130 & 2700 \\
Lambing \% & 115 & 132 & 94 & 115 \\
Average lamb sale price (\$) & 39.61 & 83 & 33.95 & 63.34 \\
Cash farm surplus (\$/ha) & 448 & 239 & 176 & 276 \\
Cash farm surplus (\$(2002)/ha) & 512 & 239 & 201 & 276 \\
\hline * Central North Island Model used here. & & & \\
\hline
\end{tabular}

become more intensively operated. These farmers are becoming increasingly aware of:

- the fragility of some soils to the long term effects of damage,

- the need to keep pastures in a highly productive state - they may renovate their whole area on a 10year cycle and incorporate brassica crops into the rotation

- the relative profitability of different classes of finishing stock and grazing dairy stock.

\section{Case studies - an update}

At this conference in 1977 three farmers gave papers in which they described their farming systems. To demonstrate the changes since, comparative case studies are offered.

The first relates to the farm of Malcolm Guy and his family (Guy 1978). The farm is located at Koputaroa, $10 \mathrm{~km}$ north of Levin. Here the soils consist of (Palmer pers. comm.):

- Sand dunes - Foxton plains sand with peat.

- Large areas of peat (some of which has an inexplicable, extremely high $\mathrm{P}$ retention).

- Alluvium closer to the stop bank - Kairanga and Parewanui.

In 1977 Malcolm, a progressive farmer, had 135 ha of his own beef farm and two blocks totalling 259 ha of both dairy and beef, 394 ha in all. Previously the home farm (breeding cows, finishing cattle and a few ewes) had been in "fat lambs and breeding cows". The farm was run as a flexible, low cost, all grass system using contractors and family to help with shifting electric fences. The dairy unit ran 325 milking cows (50 cows for winter quota milk) and sported a 28-bale rotary. The beef unit ran bull beef, dairy heifers and provided run-off grazing for the dairy herd. Livestock numbers were increasing and it seems the Livestock Incentive Scheme (LIS) was in effect on the farm.

Today Malcolm and his son farm 800 ha in total of which 120 ha are leased. They have purchased seven neighbouring properties from 10 ha to 100 ha.
They grow 20-25 ha of crop a year (including squash, onions and/or potatoes as well as maize), run three dairy herds (1100 milking cows with replacements on the beef unit) on three separate farms with three separate sheds. They also run 300 red deer and 1100 bulls (finishing about 850 each year), although the dairy herd is increasing at the expense of bulls for better pasture utilisation and less damage to soils. The Guys are still developing land, sometimes using squash as part of the rotation to establish pasture, but now there is only market price of products by way of incentive.

Malcolm identifies the local drainage scheme as having a big impact on the development of their farm. Knowing that in all but the most extreme floods their stock will be safe has given them the flexibility and confidence to expand in dairying and crop production. The Manawatu River can flood at any time of the year!

Other pressures now influence their farming policies and systems. The fertile land in Southern Horowhenua is important for vegetable and fruit crops (often for the fresh Wellington market). More recently, however, lifestyle blocks have entered the equation as the Kapiti Coast runs out of land and there is increasing pressure on the water resources (both quality and quantity) of the area. The ripple effect means that they may soon be devoting an increasing proportion of this land to feeding Wellington. The question is "how soon?" and they are faced with the uncertainty of how much time and money to put into repairs and maintenance of capital resources.

Bob Coulson was another farmer to deliver a paper at the 1977 conference (Coulson 1978). Bob farmed in the Lockwood basin - another area of highly fertile alluvium (Kairanga silt loam) and peat (Kairanga and Opiki peaty silt loams), this time associated with the Oroua River - highly fertile soils when drained appropriately, either tiled or opendrained. Bob started producing crops because livestock prices fluctuated to the detriment of the farmer but the risks of flooding were too high - stock could be moved but crops could not. The advent of the Manawatu Catchment Board's river control scheme enabled him to develop an intensive cropping system with certainty. From one or two paddocks of wheat and grass seed they moved into a three-phase cycle of grass seed to cereal to legume, 
rape or birdseed (Phalaris canariensis) and back to grass seed. The rotation could be lengthened by a year if a second crop of grass seed was taken or clover hay made. He talked of the wide range of crops that could be grown and the possibility of high returns for some crops on occasions. Of course Bob was a very good and conscientious operator whose skills were sought after when new and unknown crops were being tried.

Store stock were finished as an integral part of the system and "purchasing at auction where the buyer has to determine the type of animal that will make maximum profit in the time available" was an important management skill.

Bob is no longer farming, but his neighbour, Richard Green explained the situation 26 years later. Milling wheat is rarely grown in the region now due to the mills and Sanitarium factories having ceased operation here. Barley is grown for feed and also for malting. The area of maize for silage for purchase by dairy farmers has increased exponentially over the last few years. Returns compare favourably with grain. Squash has been a prominent crop yielding a sustainable $15 \mathrm{t} / \mathrm{ha}$. Peas for processing are a regular part of the rotation. Bulls are the stock of choice for finishing. Dairy conversion would involve high levels of investment, not considered appropriate at this time.

\section{Hill country (sheep and cattle) farms}

Hill country farms were not a feature of the 1977 conference. The statistics show them to be significant both in terms of the land area they occupy and the number of farms and farmers involved. Sheep, cattle, deer, both breeding and finishing to gether with farm forestry are successfully farmed in all imaginable combinations and from highly intensively to very extensively, depending on the landscape and the skills and inclination of the farmer. Farmers on these land classes are limited in the range of products they can produce and are not in a strong position to respond to market signals by changing their product mix except at the margins. They have got around this constraint by intensifying. It is now not unusual to see quite intensive subdivision, forage crops and modern pasture cultivars together with exotic sheep and cattle breeds and performance data that ratchet upwards each year.

The effect of this has been to push the "finishing" farms further into the hills and has resulted in the intensification of hill country. That is with the cultivable lower hills the use of brassica crops, short rotation cultivars and improved pasture species has enabled these farmers to finish their own stock.
While the statistics show the numbers of breeding ewes have decreased considerably, the introduction of exotic genes has increased ewe productivity, and hence maintained the supply of lambs for store sale or finishing. Beef cow productivity has proven more difficult.

\section{What has changed?}

Well, it is the farmers themselves who have changed. During the eighties they felt, more than all other sectors, the swift sword that was deregulation because of their lack of product options. They could not continue as they were and many did not survive.

Those who survived did so by changing their methods. Contractors have largely replaced hired farm labour as they can be used more effectively for many tasks. Bikes and quads have replaced horses meaning time is better used. Subdivision and new pasture cultivars have facilitated improved productivity. Where once super and lime were industry norms, they have been replaced by much sharper instruments in the form of high analysis fertilisers.

Along with technology, the state of mind of the farmer has changed. Product prices have fluctuated but risen, allowing new technology and electronics to be taken on board.

With the demise of free consultancy the industry has had to manage its own information exchange. Most would agree that industry has done a good job.

Farmers' knowledge of their resources has become much more accurate - the development incentives of 1977 meant decisions were distorted and the economics of development of unfarmable land versus intensification has since been resolved. Nevertheless, prices still fluctuate mercilessly and farmers must be prepared. Many would say that the need to be resilient has mitigated against the viability of corporate farms, although larger scale farms can better survive some situations.

\section{Conclusions}

The region is diverse in its landscapes and resources - particularly human - and this leads to rapid changes in farming systems as demonstrated by the data. The challenge to respond to market signals is high and farmers in this region have always moved quickly if they could see sensible ways of doing things and will continue to do so.

The region has been the focus of education, training and research in agriculture for the North Island, if not New Zealand, and our educators and scientists have served it well. Perhaps farmers have felt the burden of being over-exposed to scientists and students and of carrying more than their share of 
responsibility for field trials and exercises but the interactions have served all sectors well. Farmers have shown high levels of skills and knowledge and willingness to debate issues. Scientists and educators have also been well served.

The challenge in 2003 is to ensure that new knowledge continues to be collaboratively generated and this will require ongoing investment in both education and research.

\section{REFERENCES}

Coulson, R.K. 1978. Integrated cropping and livestock in the Manawatu. Proceedings of the New Zealand Grassland Association 39 (1): 32-37.

Guy, M. 1978. The maximum utilisation of pasture with intensive livestock production. Proceedings of the New Zealand Grassland Association 39 (1): 38-44. 